\title{
Research Square \\ Experimental Study on Single Factor, Orthogonal and Characteristics of SRB Particles Fixed by Biologically Activated Lignite
}

Junzhen Di ( $\nabla$ dijunzhen@126.com )

Liaoning University of Engineering and Technology

Yangyang Jiang

Liaoning University of Engineering and Technology

Mingjia Wang

Liaoning University of Engineering and Technology

Yanrong Dong

Liaoning University of Engineering and Technology

\section{Research Article}

Keywords: Acid mine drainage, Sulfate reducing bacteria, Lignite, Immobilization technology, Rhodopseudomonas spheroides

Posted Date: October 11th, 2021

DOI: https://doi.org/10.21203/rs.3.rs-956144/v1

License: (c) (i) This work is licensed under a Creative Commons Attribution 4.0 International License. Read Full License 


\title{
Experimental Study on Single Factor, Orthogonal and Characteristics of SRB Particles Fixed by Biologically Activated Lignite
}

\begin{abstract}
Junzhen Di ${ }^{1}{ }^{1 *}$, Yangyang Jiang ${ }^{1}$, Mingjia Wang ${ }^{1} \&$ Yanrong Dong ${ }^{1}$
Abstract : Aiming at the problems of insufficient supply of carbon source and toxic effect of heavy metal ions in the treatment of acid mine wastewater (AMD) by sulfate reducing bacteria (SRB), immobilized particles were prepared with Rhodopseudomonas spheroides, SRB and lignite as the main raw materials, and the optimal ratio of immobilized particles was determined based on single factor test and orthogonal test. The adsorption experiment of immobilized particles was carried out under the optimal ratio, the reaction kinetic process and adsorption capacity of immobilized particles for different ions were analyzed, and the action mechanism was studied. The results show that lignite not only has good adsorption performance, but also can be used as the carbon source of SRB after degradation by Rhodopseudomonas spheroides, so as to solve the problems of low removal efficiency of AMD by SRB and insufficient supply of carbon source. When the dosage of lignite, Rhodopseudomonas spheroides and $\mathrm{SRB}$ is $3 \%, 10 \%$ and $10 \%$ respectively, and the particle size of lignite is 200 mesh, the overall treatment effect is the best. The removal rates of $\mathrm{SO}_{4}^{2-}, \mathrm{Zn}^{2+}$ and $\mathrm{Cu}^{2+}$ are $83.21 \%, 99.59 \%$ and $99.93 \%$ respectively, the $\mathrm{pH}$ is increased to 7.43, the release of COD is $523 \mathrm{mg} / \mathrm{L}$, and the ORP number is $-134 \mathrm{mV}$. The reduction process of $\mathrm{SO}_{4}{ }^{2-}$ by immobilized particles conforms to the pseudo first-order kinetics, the isothermal adsorption of $\mathrm{Zn}^{2+}$ more conforms to the Freundlich isothermal adsorption equation, and the adsorption kinetics of $\mathrm{Zn}^{2+}$ more conforms to the pseudo second-order kinetic model.
\end{abstract}

Keyword: Acid mine drainage; Sulfate reducing bacteria; Lignite; Immobilization technology; Rhodopseudomonas spheroides

\section{Introduction}

Acid mine wastewater is produced with mining activities. Because of its acidity and high concentration of heavy metal ions, it will have a serious impact on the environment ${ }^{1,2}$. At present, the most commonly used methods to deal with AMD mainly include physical method, chemical method and biological method. Physical and chemical methods have problems such as high cost or unsatisfactory treatment effect, so microbial method has been widely studied. SRB is the most commonly used, but in the actual treatment process, due to the inhibition of AMD low $\mathrm{pH}$, the toxicity of heavy metal ions and the lack of carbon source in the later stage, the treatment effect of SRB is not ideal $^{1}$. Lignite has large specific surface area and rich oxygen-containing functional groups. Heavy metal ions are easy to combine with oxygen-containing functional groups on the surface of lignite; As a coal dissolving bacterium, Rhodopseudomonas spheroides can degrade lignite for SRB for growth and metabolism. Therefore, using the biodegradable lignite as the carbon source of SRB can improve the $\mathrm{pH}$ of water and reduce the toxicity of acid and heavy metal ions to $\mathrm{SRB}^{2-4}$. In this experiment, biologically activated lignite was used as SRB carbon source to explore the optimal ratio of immobilized particle composition of mineral carbon source in the treatment of AMD by immobilization technology, and the reaction kinetic process and adsorption capacity of immobilized particles to $\mathrm{SO}_{4}{ }^{2-}$ and $\mathrm{Zn}^{2+}$ were analyzed, so as to provide a strong basis for selecting minerals as carbon source for SRB treatment of acid mine wastewater.

\section{Experimental Methods}

\subsection{Single Factor Experiment and Orthogonal Experiment}

According to the preparation method of immobilized particles 5,6 groups of Rhodopseudomonas spheroides immobilized particles with different mass fractions $(0 \%, 10 \%, 20 \%, 30 \%, 40 \%, 50 \%), 4$ groups of lignite 
immobilized particles with different mass fractions $(1 \%, 3 \%, 5 \%, 7 \%), 3$ groups of immobilized particles with different SRB bacterial dosage $(10 \%, 30 \%, 50 \%)$ and 3 groups of immobilized particles with different lignite particle sizes ( 80 mesh, 100 mesh 200 mesh) were prepared successively, and activated in an improved Starkey medium solution without organic components for 12 hours. Different immobilized particles were added to $300 \mathrm{ml}$ of wastewater according to the solid-liquid ratio of 1:10, and placed in a constant temperature shaking table at $30^{\circ} \mathrm{C}$ and $150 \mathrm{r} / \mathrm{min}$ for continuous oscillation for single factor test ${ }^{6}$. Among them, the initial concentrations of $\mathrm{SO}_{4}{ }^{2-}$, $\mathrm{Cu}^{2+}, \mathrm{Zn}^{2+}, \mathrm{Ca}^{2+}$ and $\mathrm{Mg}^{2+}$ in the wastewater are $816 \mathrm{mg} / \mathrm{L}, 10 \mathrm{mg} / \mathrm{L}, 20 \mathrm{mg} / \mathrm{L}, 100 \mathrm{mg} / \mathrm{L}$ and $50 \mathrm{mg} / \mathrm{L}$ respectively, and the initial $\mathrm{pH}$ value is 4.0. Based on the single factor test results, $\mathrm{L}_{9}\left(3^{4}\right)$ orthogonal test is carried out for the above four factors. Table 1 is the specific test scheme. The removal rate of $\mathrm{SO}_{4}^{2-}, \mathrm{Cu}^{2+}, \mathrm{Zn}^{2+}$ in wastewater, the effect of $\mathrm{pH}$ improvement, the release of COD and the change of ORP value were analyzed by single factor real test and orthogonal test. Among them, the concentration of $\mathrm{SO}_{4}{ }^{2-}$ is determined by $\mathrm{V}-1600 \mathrm{PC}$ visible spectrophotometer (HJ/T 342-2007), the concentration of $\mathrm{Cu}^{2+}$ and $\mathrm{Zn}^{2+}$ is determined by Z-2000 flame atomic spectrophotometer (GB/T 7475-2015), the pH of the solution is determined by PHS-3C pH meter (GB/T 6920-2015), the content of COD is determined by ET99730 COD tester (HJ/T 399-2007), and the ORP value is determined by calomel electrode (SL 94-1994).

\subsection{Characteristic Experiment}

Conduct $\mathrm{SO}_{4}{ }^{2-}$ and $\mathrm{Zn}^{2+}$ characteristic test on the immobilized particles with the best composition ratio: Configure the simulated wastewater containing only $816 \mathrm{mg} / \mathrm{L} \mathrm{SO}_{4}{ }^{2-}$ concentration, adjust the $\mathrm{pH}$ of the wastewater to 4 , put it in the wastewater according to the solid-liquid ratio of 1:10, and continuously vibrate in a shaking table at $30^{\circ} \mathrm{C}$ and $150 \mathrm{r} / \mathrm{min}$. At $6 \mathrm{~h}, 12 \mathrm{~h}, 24 \mathrm{~h}, 48 \mathrm{~h}, 72 \mathrm{~h}, 96 \mathrm{~h}$ and $120 \mathrm{~h}$ after the start of the test, the concentration of residual $\mathrm{SO}_{4}{ }^{2-}$ and the changes of $\mathrm{pH}, \mathrm{COD}$ and ORP values shall be measured until the residual concentration of $\mathrm{SO}_{4}{ }^{2-}$ is stable; Prepare $20 \mathrm{mg} / \mathrm{L}$ of simulated wastewater containing only $\mathrm{Zn}^{2+}$, adjust the $\mathrm{pH}$ value of the solution to 4.0 , take $30 \mathrm{~g}$ of immobilized particles in $300 \mathrm{ml}$ of wastewater according to the ratio of solid-liquid ratio of 1:10, and shake continuously in a shaking table at $30^{\circ} \mathrm{C}$ and $150 \mathrm{r} / \mathrm{min}$. At $3 \mathrm{~h}, 6 \mathrm{~h}, 9 \mathrm{~h}, 12 \mathrm{~h}, 24 \mathrm{~h}, 48 \mathrm{~h}, 72 \mathrm{~h}, 96 \mathrm{~h}$ and $120 \mathrm{~h}$ after the start of the test, the concentration of residual $\mathrm{Zn}^{2+}$, the changes of $\mathrm{pH}, \mathrm{COD}$ and ORP values shall be measured until the concentration of each ion in the system is stable.

\section{Experimental Results and Discussion}

\subsection{Results of Single Factor Experiment}

According to Fig. 1, when the dosage of Rhodopseudomonas spheroides is $30 \%$, the removal effect of $\mathrm{SO}_{4}{ }^{2-}$ is the best; When the dosage of Rhodopseudomonas spheroides is $20 \%$, the removal effect of $\mathrm{Cu}^{2+}$ and $\mathrm{Zn}^{2+}$ is the best; When the dosage of Rhodopseudomonas spheroides is $50 \%$, the effect of $\mathrm{pH}$ enhancement is the best; When the dosage of Rhodopseudomonas spheroides is $30 \%$, it has the best effect on stimulating SRB activity.

According to Fig. 2, when the lignite dosage is $5 \%$, the $\mathrm{SO}_{4}{ }^{2-}$ removal effect is the best; When the dosage of lignite is $5 \%$, the removal effect of $\mathrm{Cu}^{2+}$ is the best; When the dosage of lignite is $1 \%$, the removal effect of $\mathrm{Zn}^{2+}$ is the best; When the dosage of lignite is $5 \%$, it has the best effect on increasing the $\mathrm{pH}$ of the solution; When the dosage of lignite is $5 \%$, it has the best effect on stimulating SRB activity.

According to Fig. 3, when the SRB dosage is $30 \%$, the $\mathrm{SO}_{4}{ }^{2-}$ removal effect is the best; When SRB dosage is $10 \%$, the removal effect of $\mathrm{Cu}^{2+}$ is the best; When SRB dosage is $30 \%$, the removal effect of $\mathrm{Zn}^{2+}$ is the best; When SRB dosage is $10 \%$, it has the best effect on increasing the $\mathrm{pH}$ of the solution; When the dosage of SRB is $30 \%$, it has the best effect on stimulating SRB activity.

According to Fig. 4, when the particle size of lignite is 100 mesh, the removal effect of $\mathrm{SO}_{4}{ }^{2-}$ is the best; When the particle size of lignite is 80 mesh, the removal effect of $\mathrm{Cu}^{2+}$ is the best; When the particle size of lignite is 200 
mesh, the removal effect of $\mathrm{Zn}^{2+}$ is the best; When the particle size of lignite is 200 mesh, it has the best effect on increasing the $\mathrm{pH}$ of the solution; Lignite with particle size of 200 mesh has the best effect on stimulating SRB activity.

\subsection{Analysis of The Results of Orthogonal Experiment}

The orthogonal test was carried out on the basis of the optimal dosage of each factor of immobilized particles obtained from the previous single factor test (the dosage of Rhodopseudomonas spheroides was $30 \%$; the dosage of lignite was 5\%; the dosage of SRB bacteria was 30\%; and the particle size of lignite was 200 mesh).

The range of a factor in the orthogonal test results is positively correlated with the effect of affecting the test results. The greater the range, the greater the influence of the influencing factor on the test results ${ }^{7-9}$. According to Table 1, the order of influence of various factors on $\mathrm{SO}_{4}{ }^{2-}$ removal effect is: $\mathrm{A}>\mathrm{D}>\mathrm{C}>\mathrm{B}$. The analysis of variance is mainly carried out with item $\mathrm{B}$, as shown in Table 2 and Table 3. The $\mathrm{P}$ value of the four factors and their influence in this experiment is very low $(\mathrm{P}<0.05)$, indicating that the four factors have no significant correlation with the removal effect of $\mathrm{SO}_{4}{ }^{2-}$. According to the mean value of four factors ${ }^{10}$, when the combination type of immobilized particles is $\mathrm{A}_{1} \mathrm{~B}_{1} \mathrm{C}_{1} \mathrm{D}_{3}$, the removal effect of $\mathrm{SO}_{4}{ }^{2-}$ is the best.

According to Table 1, the order of influence of various factors on $\mathrm{Cu}^{2+}$ removal effect is: $\mathrm{A}>\mathrm{D}>\mathrm{C}>\mathrm{B}$. The analysis of variance based on item B is shown in Table 2 and Table 3. The results show that the removal effect of factor $\mathrm{A}$ on $\mathrm{Cu}^{2+}$ is significant, and factors $\mathrm{B}, \mathrm{C}$ and $\mathrm{D}$ are not significant. According to the mean value of the four factors, when the combination type of immobilized particles is $\mathrm{A}_{1} \mathrm{~B}_{2} \mathrm{C}_{2} \mathrm{D}_{3}$, the removal effect of $\mathrm{Cu}^{2+}$ is the best.

According to Table 1, the order of influence of various factors on $\mathrm{Zn}^{2+}$ removal effect is: $\mathrm{D}>\mathrm{A}>\mathrm{B}>\mathrm{C}$. The analysis of variance based on item $\mathrm{C}$ is shown in Table 2 and Table 3. The results show that the removal effect of factors $\mathrm{A}, \mathrm{B}$ and $\mathrm{C}$ on $\mathrm{Zn}^{2+}$ is not significant, and factor $\mathrm{D}$ is significant. According to the mean value of the four factors, when the removal effect of $\mathrm{Zn}^{2+}$ is the best, the optimal type of immobilized particle combination is $\mathrm{A}_{1} \mathrm{~B}_{3} \mathrm{C}_{1} \mathrm{D}_{3}$.

According to Table 1, the order of the influence of various factors on the $\mathrm{pH}$ enhancement effect is: $\mathrm{A}=\mathrm{C}>$ $\mathrm{D}>\mathrm{B}$. The analysis of variance based on item B is shown in Table 2 and Table 3. The results show that the four factors have no significant correlation with the effect of $\mathrm{pH}$ improvement. According to the mean value of the four factors, the optimal combination type of immobilized particles with the best effect on $\mathrm{pH}$ improvement is $\mathrm{A}_{3} \mathrm{~B}_{3} \mathrm{C}_{3} \mathrm{D}_{3}$.

According to Table 1, the order of influence of various factors on COD release is: A $>$ D $>$ B $>$ C. The analysis of variance based on item $\mathrm{C}$ is shown in Table 2 and Table 3. The results show that factors $A, B$ and D show significant differences in COD release, while factor $\mathrm{C}$ shows no significant differences. According to the mean value of the four factors, the optimal combination type of immobilized particles affecting cod release is $A_{3} B_{1} C_{2} D_{3}$.

According to Table 1, the order of influence of various factors on ORP value change is: $A>D>B>C$. The analysis of variance is mainly carried out with item $C$, as shown in Table 2 and Table 3. The experimental results show that factors $A$ and $D$ show a significant level on the change of ORP value, while factors $B$ and $C$ show a non significant level. According to the mean value of the four factors, the best combination type of immobilized particles affecting the change of ORP value is $\mathrm{A}_{1} \mathrm{~B}_{1} \mathrm{C}_{1} \mathrm{D}_{1}$.

\subsection{Analysis of Characteristic Test Results}

\subsubsection{Physical Properties of Particles}

The immobilized particles were prepared according to the best composition ratio obtained by orthogonal test. The particle morphology before and after AMD treatment is shown in Supplementary Figure S1. Before the treatment of AMD with immobilized particles, the appearance was spherical with smooth surface, hard texture, no 
obvious agglomeration, and the inner black core was faint under the white coat; After AMD treatment, the appearance of the immobilized particles presents a full spherical shape, but the texture becomes softer and more moist, and the black core of the particles is clearly visible ${ }^{11}$.

\subsubsection{Kinetics of $\mathrm{SO}_{4}{ }^{2-}$ Reduction}

As the reaction continues, the overall change trend of $\mathrm{SO}_{4}{ }^{2-}$ removal rate is gradually increased at first and then stabilized, and the $\mathrm{SO}_{4}{ }^{2-}$ concentration in the system gradually decreases to a stable level. When the reaction lasted for 1 day, the reduction rate of $\mathrm{SO}_{4}{ }^{2-}$ was $12.283 \mathrm{mg} /(\mathrm{L} \cdot \mathrm{h})$; The average reduction rate of $\mathrm{SO}_{4}{ }^{2-}$ in $1-4$ days was $5.839 \mathrm{mg} /(\mathrm{L} \cdot \mathrm{h})$; When the reaction reaches $5 \mathrm{~d}$, the reduction rate of $\mathrm{SO}_{4}{ }^{2-}$ is only 0.840 $\mathrm{mg} /(\mathrm{L} \cdot \mathrm{h})$ (Supplementary Figure S2(a)). SRB is a microorganism that uses sulfur oxide such as sulfate as electron receptor to obtain energy supply ${ }^{12}$. The test results show that SRB immobilized particles have strong adaptability to the environment, and SRB can quickly enter the state of high growth rate and vigorous metabolism ${ }^{13}$. The fundamental reason is that at the initial stage of the reaction, Rhodopseudomonas spheroides degraded lignite into organic matter that can be utilized by SRB ${ }^{14-15}$. The rich organic matter in the system promoted the growth of SRB, enhanced microbial SRB activity and promoted the removal of $\mathrm{SO}_{4}{ }^{2-5}$; Lignite can also adsorb heavy metal ions and $\mathrm{H}^{+}$in the system, reduce environmental load and reduce the stimulation of metal ions and peracid conditions on SRB. According to the $\mathrm{pH}$ change curve of the solution, the environment of the system in the early stage of the reaction is too acidic. When the $\mathrm{pH}$ is between 7-8, the SRB activity is the best, and both acid and alkali will inhibit the SRB activity. Therefore, the growth and activity of SRB in the early stage of the reaction are inhibited, which is consistent with the results of this test; When the $\mathrm{pH}$ value gradually increases to 7-8, the SRB activity is the best. However, with the continuous occurrence of the reaction, the nutrients in the system are gradually consumed, and the $\mathrm{SO}_{4}{ }^{2-}$ content is gradually reduced due to the reduction, so that the SRB growth rate and activity are slowed down in the later stage of the reaction, and the removal efficiency of $\mathrm{SO}_{4}{ }^{2-}$ is reduced ${ }^{6}$, and the sediment produced by the early reaction is attached to the particle surface, It blocks the internal channel of the particles and affects the ion exchange reaction between the particles and the outside ${ }^{16}$, so the SRB activity is inhibited and the removal effect of $\mathrm{SO}_{4}{ }^{2-}$ is reduced.

The adsorption kinetic process of $\mathrm{SO}_{4}^{2-}$ by immobilized particles was analyzed by zero order kinetic model and first-order kinetic model respectively, and See equations (1) and (2) for the expression:

$$
\begin{gathered}
C_{t}=C_{0}-k_{0} t \\
\ln C_{t}=\ln C_{0}-k_{1} \cdot t
\end{gathered}
$$

In the formula: $C_{0}$ - Initial concentration of $\mathrm{SO}_{4}{ }^{2-}, \mathrm{mg} / \mathrm{L}$;

$$
\begin{aligned}
& C_{t}-\text { The concentration of } \mathrm{SO}_{4}^{2-} \text { at } t, \mathrm{mg} / \mathrm{L} ; \\
& k_{0}-\text { Zero order reaction rate constant, } \mathrm{mg} / \mathrm{L}^{-1} \cdot \mathrm{h}^{-1} \text {; } \\
& k_{1} \_ \text {First order reaction rate constant, } \mathrm{h}^{-1} \text {. }
\end{aligned}
$$

According to the fitting results(Fig. 5(a, b)), we can know the $\mathrm{SO}_{4}{ }^{2-}$ reduction kinetic parameters. According to the $\mathrm{SO}_{4}{ }^{2-}$ reduction kinetic fitting parameters, for the linear correlation coefficient $R^{2}$, the first-order reduction kinetic model is greater than the zero order reduction kinetic model, indicating that the first-order reduction kinetic model can more accurately describe the $\mathrm{SO}_{4}{ }^{2-}$ reduction reaction process than the zero order reduction kinetic 
model, The linear correlation coefficient of the first-order reduction kinetic model was $R^{2}=0.98821$. It shows that the reduction process of $\mathrm{SO}_{4}{ }^{2-}$ is mainly electron receptor ${ }^{17}$.

According to Fig. 5(c), with the progress of the reaction, the $\mathrm{pH}$ first increased and then stabilized, and finally showed weak alkalinity, $\mathrm{pH}=8.1$. The initial $\mathrm{pH}$ of the system is 4.0. The peracid reaction conditions are not conducive to the growth and metabolism of SRB, and the SRB activity is low. At this time, the pH rise of the solution is mainly due to the rich ionizable groups $\left(\mathrm{RCOOH} \rightleftharpoons \mathrm{RCOO}^{-}+\mathrm{H}^{+}\right)$in the lignite inside the immobilized particles, which has a good two-way $\mathrm{pH}$ regulation ability ${ }^{18}$. Therefore, the high concentration of $\mathrm{H}^{+}$in the system before the reaction will inhibit the dissociation of active groups, the dissociation equilibrium moves reversely, and the $\mathrm{pH}$ value of the solution gradually increases. At this time, the adsorption is mainly physical adsorption, mainly ion exchange ${ }^{19}$; However, the ability of lignite to adjust $\mathrm{pH}$ is limited, so when the $\mathrm{pH}$ value rises to a certain extent and the physiological activity of SRB is no longer inhibited, SRB begins to actively carry out $\mathrm{SO}_{4}{ }^{2-}$ reduction reaction. At this time, the root cause of the decrease of $\mathrm{H}^{+}$concentration in the system is the biochemical reaction of $\mathrm{SRB}$. The $\mathrm{H}^{+}$in the solution provides electrons for $\mathrm{SRB}$ to reduce $\mathrm{SO}_{4}{ }^{2-}$ and improves the $\mathrm{pH}$ of the solution to a great extent. Until the later stage of the reaction, although the $\mathrm{pH}$ of the system is very suitable for the growth and metabolism of SRB, the concentration of $\mathrm{SO}_{4}{ }^{2-}$ in the system is low and the content of electron receptor is insufficient, resulting in the ability of SRB to reduce $\mathrm{SO}_{4}{ }^{2-}$ was reduced and the demand for $\mathrm{H}^{+}$, so the $\mathrm{pH}$ value of the system finally tends to be stable.

The overall change trend of COD release is that it increases gradually with the reaction, decreases after a period of reaction, and then increases gradually. The final release of COD is $700 \mathrm{mg} / \mathrm{L}$. The above changes in COD release are related to the leakage of organic matter released from lignite and SRB biological metabolites in immobilized particles ${ }^{16}$. At the initial stage of the reaction, Rhodopseudomonas spheroides degraded the lignite, so that the lignite was degraded into organic matter, and a large amount of organic matter leaked out. At the initial stage, SRB was not enough to make use of such rich organic matter, so the organic matter in the solution gradually accumulated and the COD content increased. With the progress of the reaction, the activity of SRB and the ability to use organic matter are enhanced. The lignite degraded into organic matter provides carbon source for the growth of SRB, promotes the growth and metabolism of SRB, and the organic matter in the solution is gradually consumed, so the organic matter content shows a downward trend. When the reaction proceeds to the later stage, more sediments are attached to the lignite surface, which makes the lignite degradation process more difficult, the organic carbon source available for SRB growth and metabolism in the system is reduced, the SRB activity and the ability to utilize organic matter are limited, and the COD in the system begins to accumulate again.

The overall change trend of ORP value is: It gradually decreases and then tends to be stable, and the final ORP value of the system was $-136 \mathrm{mV}$. The lower the ORP value, the better the bacterial activity in the system. The test results showed that the SRB activity in the reaction system gradually increased until the SRB activity remained unchanged. At the initial stage of the reaction, lignite is both a carbon source and an electron donor of $\mathrm{SRB}^{20}$. Lignite degraded by Rhodopseudomonas spheroides provides nutrients for SRB growth and metabolism and enhances SRB activity; Lignite can also be used as an electron donor of SRB to further enhance SRB activity, so the ORP value decreases. In the later stage of the reaction, due to the limitation of the content of carbon source and terminal electron receptor, the proliferation activity of SRB is inhibited and the activity is low. Therefore, the ORP value tends to be stable, and the gradual adsorption saturation of lignite to $\mathrm{H}^{+}$is also one of the reasons.

3.3.3 Adsorption Capacity of $\mathrm{Zn}^{2+}$ and Analysis of Fitting Results of Isotherm Adsorption Equation

(1) Adsorption capacity and isotherm adsorption equation of $\mathrm{Zn}^{2+}$

$$
q_{e}=\frac{\left(C_{0}-C_{e}\right) \cdot V}{M}
$$


In the formula: $q_{e}$ Equilibrium adsorption capacity of $\mathrm{Zn}^{2+}$ on particles, $\mathrm{mg} / \mathrm{g}$;

$$
\begin{aligned}
& C_{0} 、 C_{e}-\text { Initial and equilibrium concentrations of } \mathrm{Zn}^{2+} \text { in solution, } \mathrm{mg} / \mathrm{L} \text {; } \\
& V-\text { Volume of } \mathrm{Zn}^{2+} \text { Solution, } \mathrm{L} \text {; } \\
& M-\text { Dosage of particles, } \mathrm{g} .
\end{aligned}
$$

See equation (3) for adsorption equation, and the adsorption capacity of $\mathrm{Zn}^{2+}$ by immobilized particles gradually increases with the increase of equilibrium concentration (Supplementary Figure S2(b)), and the adsorption rate of $\mathrm{Zn}^{2+}$ by particles in the early stage is fast, and then the rate gradually slows down. When the equilibrium concentration is $8.6175 \mathrm{mg} / \mathrm{L}$, the equilibrium adsorption capacity of $\mathrm{Zn}^{2+}$ by particles is $0.759 \mathrm{mg} / \mathrm{g}$. Langmuir and Freundlich ${ }^{21}$ isothermal adsorption equations are used to fit the isothermal adsorption process of $\mathrm{Zn}^{2+}$ respectively. See equations (4) and (5) for isothermal adsorption equation:

$$
\begin{gathered}
q_{e}=\frac{b \cdot q_{\max } \cdot C_{e}}{1+b \cdot C_{e}} \\
q_{e}=k \cdot C_{e}^{\frac{1}{n}}
\end{gathered}
$$

In the formula: $b \longrightarrow$ Constant, which is related to the enthalpy of adsorption reaction, expressed as reciprocal of concentration;

$k-$ Freundlich adsorption coefficient;

$n-$ Constant, which indicates the relative size of surface heterogeneity and adsorption strength of adsorbent, is usually greater than 1 ;

$$
q_{\max }-\text { Maximum theoretical adsorption capacity of } \mathrm{Zn}^{2+} \text { on particles, } \mathrm{mg} / \mathrm{g} .
$$

\section{(2) Analysis of fitting results}

According to the fitting results (Fig. 5(d, e)), the isotherms of the two isothermal adsorption types are regular, non negative and concave to the concentration axis, and the adsorption reaches equilibrium at high concentration ${ }^{17}$. For the linear correlation coefficient $R^{2}$, both Freundlich isothermal adsorption equation and Langmuir isothermal adsorption equation are greater than 0.95 , indicating that the adsorption of $\mathrm{Zn}^{2+}$ on the particle surface is mainly chemical adsorption, and for the adsorption correlation coefficient, Freundlich isothermal adsorption equation is greater than Langmuir isothermal adsorption equation. Therefore, Freundlich isothermal adsorption equation can more accurately describe the adsorption process of $\mathrm{Zn}^{2+}$ in $\mathrm{AMD}$ wastewater than Langmuir isothermal adsorption equation. The detailed analysis of the parameters of Freundlich isothermal adsorption equation shows that Freundlich isothermal adsorption equation is used to describe the heterogeneity of adsorbent surface and the adsorption strength of adsorbent $1 / n=0.41701,0.1<1 / n<0.5$. The results show that the immobilized particles have strong heterogeneity ${ }^{22}$ and the $\mathrm{Zn}^{2+}$ adsorption process on lignite surface is easy to occur ${ }^{23-24}$.

\subsubsection{Adsorption Kinetics of $\mathrm{Zn}^{2+}$}

Langergren equation (pseudo first-order kinetic model) and McKay equation (pseudo second-order kinetic model) are used to study the adsorption kinetic process of $\mathrm{Zn}^{2+}$ by immobilized particles. See equations (6) and (7) for the expression:

$$
\ln \left(q_{e}-q_{t}\right)=\ln q_{t}-k_{1} \cdot t
$$




$$
\frac{t}{q_{t}}=\frac{1}{k_{2} \cdot q_{e}^{2}}+\frac{t}{q_{e}}
$$

In the formula: $q_{t} \longrightarrow$ The adsorption capacity at the time of adsorption time $t, \mathrm{mg} / \mathrm{g}$;

$t$ - Adsorption time, min;

$k_{1} \_$Rate constant of pseudo first order kinetic reaction, $\min ^{-1}$;

$k_{2} \ldots$ Pseudo second order kinetic rate constant, $\mathrm{g} /(\mathrm{mg} \cdot \mathrm{min})$;

$h$ - Initial adsorption rate, $h=k_{2} \cdot q_{e}^{2}, \mathrm{mg} /(\mathrm{g} \cdot \mathrm{min})$.

According to Fig. 5(f, g), the adsorption capacity of $\mathrm{Zn}^{2+}$ by immobilized particles gradually increases with the progress of the reaction until it is stable. When the adsorption reaches equilibrium, the equilibrium adsorption capacity of $\mathrm{Zn}^{2+}$ by immobilized particles is $0.2 \mathrm{mg} / \mathrm{g}$. The kinetic model is fitted based on the adsorption curve model, and the primary and secondary kinetic fitting diagrams of $\ln \left(q_{e} /\left(q_{e}-q_{t}\right)\right) \sim t$ and $t / q_{\tau} \sim t$ are drawn respectively (Fig. 5(h, i)).

In this experiment, in the reaction stage with fast adsorption rate of $\mathrm{Zn}^{2+}$, chemical precipitation and biological adsorption exist at the same time, and the first process is chemical precipitation; In the later stage, the adsorption reaction of $\mathrm{Zn}^{2+}$ is mainly biosorption. Chemical precipitation works through lignite in the particle. Lignite adsorbs a large number of positively charged metal ions in the solution by virtue of its developed specific surface area and rich oxygen-containing functional groups; $\mathrm{SO}_{4}{ }^{2-}$ is reduced to sulfide by $\mathrm{SRB}$ and combined with the remaining $\mathrm{Zn}^{2+}$ not adsorbed by lignite in the solution to form precipitation, which is removed.

The fitting results show that the pseudo second-order kinetic regression coefficient is greater than the pseudo first-order kinetic regression coefficient, and the pseudo second-order kinetic regression coefficient $R^{2}=0.99992$, and the correlation is very high. In this case, the pseudo second-order kinetics can more accurately describe the adsorption behavior of immobilized particles on $\mathrm{Zn}^{2+} 25$. It shows that the adsorption process of $\mathrm{Zn}^{2+}$ by immobilized particles is dominated by chemical adsorption, and the influence of chemical adsorption is higher than that of mass transfer step control ${ }^{26-28}$.

The $\mathrm{pH}$ value of the solution increased first and then tended to be stable as a whole (Fig. 5(j)). Lignite in the particle contains rich active groups. The dissociation of active groups $\left(\mathrm{RCOOH} \rightleftharpoons \mathrm{RCOO}+\mathrm{H}^{+}\right)$makes the lignite surface negatively charged. At the initial stage of the reaction, the $\mathrm{pH}$ of the solution is 4 , indicating that there is a large amount of $\mathrm{H}^{+}$in the solution, and the negatively charged lignite on the surface is very easy to attract positively charged $\mathrm{H}^{+}$, resulting in the decrease of $\mathrm{H}^{+}$content in the solution, so the $\mathrm{pH}$ value of the solution increases; Moreover, as the $\mathrm{pH}$ of the solution gradually approaches neutral, the SRB activity in the system also increases. In addition to the adsorption of lignite on $\mathrm{H}^{+}$, the process of $\mathrm{SRB}$ reducing $\mathrm{SO}_{4}{ }^{2-}$ has also become a way to consume $\mathrm{H}^{+}$, and the $\mathrm{pH}$ value of the solution gradually increases with the decrease of $\mathrm{H}^{+}$concentration. As shown in the test results, the $\mathrm{pH}$ of the solution can be increased rapidly when the two reactions act at the same time. However, with the continuous occurrence of the reaction, the spare sites on the lignite surface are gradually occupied by metal ions and $\mathrm{H}^{+}$, resulting in the reduction of its adsorption capacity. Moreover, the precipitates produced by the early reaction adhere to the lignite surface, blocking the internal channels of lignite and further affecting the adsorption capacity of lignite. Therefore, the $\mathrm{pH}$ value of the later system basically does not change. In addition, in the early stage of the reaction, the $\mathrm{pH}$ of the solution has been raised to neutral, the $\mathrm{H}^{+}$concentration in the solution is low, and the ability to provide electrons for SRB is weak. Therefore, the $\mathrm{H}^{+}$concentration in the 
system basically does not change significantly, and the $\mathrm{pH}$ of the solution tends to be stable.

The overall change of COD shows a trend of first increasing, then decreasing, and then increasing. Finally, the cumulative release of COD is $1090 \mathrm{mg} / \mathrm{L}$. The organic matter released from lignite and the leakage of SRB biological metabolites in immobilized particles are the reasons affecting the change of COD release. The gradual increase of COD content in the initial stage of the reaction is due to the degradation of Lignite by Rhodopseudomonas spheroides, which releases a large amount of organic matter. At the initial stage, SRB activity is low and all organic matter can not be used quickly, resulting in the overflow of some organic matter, the increase of organic matter content in the solution and the gradual increase of COD. As the reaction proceeds, SRB begins to adapt to the current living environment and uses the degraded lignite as the carbon source for its own proliferation. Sufficient carbon source in the system can accelerate the growth and metabolism of SRB and enhance the activity of SRB, while organic matter can be utilized by SRB, so the release of COD in the solution is reduced. In the later stage of the reaction, the growth, metabolism and activity of SRB are affected by the content of carbon source and terminal electron receptor, resulting in the limited utilization of COD by SRB. Therefore, COD accumulates again and the release increases.

The ORP value first decreased and then stabilized with the increase of reaction time. The final ORP value of the system was $-106 \mathrm{mV}$. The results showed that the SRB activity in the reaction system increased gradually and remained unchanged. Combined with the $\mathrm{pH}$ change diagram, it can be seen that due to dissociation of active groups, the lignite surface inside the particles is negatively charged, and has obvious adsorption on positively charged heavy metal ions and $\mathrm{H}^{+}$, so it reduces the toxic effect of acid and heavy metal ions on SRB in AMD, enhances SRB activity, and the ORP value of the system decreases; Moreover, under the degradation of Rhodopseudomonas spheroides, lignite also acts as a carbon source for SRB proliferation, provides nutrients for SRB growth and metabolism, further enhances SRB activity and reduces ORP of the system. At the later stage of the reaction, the solution environment has been neutral and lignite has basically reached adsorption saturation, and the change of $\mathrm{H}^{+}$concentration in the solution is not obvious, indicating that there are less electrons in the system for $\mathrm{SRB}$ reduction of $\mathrm{SO}_{4}{ }^{2-}$ process. At this time, $\mathrm{SRB}$ activity is low, and ORP value basically does not change. The change trend of ORP value in the experimental results is consistent with the change law of $\mathrm{pH}$.

\section{Conclusion}

(1) The single factor experiment shows that when the dosage of Rhodopseudomonas spheroides is $30 \%$, the dosage of lignite is $5 \%$, the dosage of SRB is $30 \%$ and the particle size of lignite is 200 mesh, the biological activated lignite fixed SRB particles has the best effect on AMD treatment.

(2) Based on the single factor experiment of the ratio of immobilized particles in the early stage, based on the orthogonal experiment, combined with the changes of $\mathrm{SO}_{4}{ }^{2-}, \mathrm{Cu}^{2+}, \mathrm{Zn}^{2+}$ removal rate, $\mathrm{pH}$ improvement effect, COD release and ORP value in the solution, it is finally determined that the best combination of biologically activated lignite immobilized SRB particles is $\mathrm{A}_{1} \mathrm{~B}_{1} \mathrm{C}_{1} \mathrm{D}_{3}$. That is, the dosage of Rhodopseudomonas spheroides in the immobilized particles is $10 \%$, and the dosage of lignite is 3\%, SRB dosage is $10 \%$ and lignite particle size is 200 mesh. Under this ratio, the removal rates of $\mathrm{SO}_{4}{ }^{2-}, \mathrm{Zn}^{2+}$ and $\mathrm{Cu}^{2+}$ by immobilized particles were $83.21 \%, 99.59 \%$ and $99.93 \%$, the $\mathrm{pH}$ was raised to 7.43 , the COD release was $523 \mathrm{mg} / \mathrm{L}$ and the ORP value was $-134 \mathrm{mV}$.

(3) The reduction process of $\mathrm{SO}_{4}{ }^{2-}$ by immobilized particles conforms to the pseudo first-order kinetics, and the fitting equation is: $y=-0.02019 \cdot x+6.73245, R^{2}=0.98821$. The main factor affecting the reduction process is electron receptor.

(4) The isothermal adsorption of $\mathrm{Zn}^{2+}$ by immobilized particles is more in line with Freundlich isothermal 
adsorption equation, and the fitting equation is: $q_{e}=0.32156 \cdot C_{e}^{0.41701}, R^{2}=0.96532$. When the equilibrium concentration is $8.6175 \mathrm{mg} / \mathrm{L}$, the equilibrium adsorption capacity can reach $0.759 \mathrm{mg} / \mathrm{g}$. The results show that the lignite in the immobilized particles can easily adsorb $\mathrm{Zn}^{2+}$, and the surface of the adsorbent is uneven; The adsorption kinetics of $\mathrm{Zn}^{2+}$ by lignite inside the immobilized particles is more in line with the pseudo second-order kinetic model, and the fitting equation is: $y=5.07431 \cdot x+0.14878, R^{2}=0.99992$. It shows that the adsorption of $\mathrm{Zn}^{2+}$ by lignite is mainly chemical adsorption. 
Table1 $\mathrm{L}_{9}\left(3^{4}\right)$ orthogonal test and result

\begin{tabular}{|c|c|c|c|c|c|c|c|c|c|c|}
\hline $\begin{array}{l}\text { Serial } \\
\text { number }\end{array}$ & $\begin{array}{c}\text { Rhodopseudomonas } \\
\text { spheroides } \\
\text { A/\% }\end{array}$ & $\begin{array}{c}\text { Lignite } \\
\text { content } \\
\mathrm{B} / \%\end{array}$ & $\begin{array}{l}\text { SRB } \\
\mathrm{C} / \%\end{array}$ & $\begin{array}{c}\text { Particle size of } \\
\text { lignite } \\
\text { D/mesh }\end{array}$ & $\begin{array}{l}\mathrm{SO}_{4}^{2-} \text { Test } \\
\text { result }\end{array}$ & $\begin{array}{c}\mathrm{Cu}^{2+} \text { Test } \\
\text { result }\end{array}$ & $\begin{array}{c}\mathrm{Zn}^{2+} \text { Test } \\
\text { result }\end{array}$ & $\begin{array}{c}\mathrm{pH} \text { Test } \\
\text { result }\end{array}$ & $\begin{array}{l}\text { COD Test } \\
\text { result }\end{array}$ & $\begin{array}{l}\text { ORP Test } \\
\text { result }\end{array}$ \\
\hline 1 & 10 & 3 & 10 & 80 & 80.96 & 99.18 & 96.77 & 7.13 & 499 & -134 \\
\hline 2 & 10 & 5 & 30 & 100 & 77.70 & 99.93 & 95.58 & 7.28 & 482 & -129 \\
\hline 3 & 10 & 7 & 50 & 200 & 82.28 & 99.18 & 99.59 & 7.42 & 516 & -123 \\
\hline 4 & 30 & 3 & 30 & 200 & 75.17 & 98.81 & 98.28 & 7.31 & 511 & -119 \\
\hline 5 & 30 & 5 & 50 & 80 & 71.77 & 96.57 & 95.66 & 7.23 & 479 & -124 \\
\hline 6 & 30 & 7 & 10 & 100 & 72.21 & 95.59 & 96.58 & 7.23 & 485 & -120 \\
\hline 7 & 50 & 3 & 50 & 100 & 81.49 & 93.05 & 94.67 & 7.43 & 516 & -119 \\
\hline 8 & 50 & 5 & 10 & 200 & 83.21 & 95.59 & 97.12 & 7.35 & 521 & -114 \\
\hline 9 & 50 & 7 & 30 & 80 & 75.21 & 94.74 & 95.00 & 7.36 & 523 & -116 \\
\hline
\end{tabular}

Table2 Intuitive analysis table

\begin{tabular}{|c|c|c|c|c|}
\hline Serial number & $\begin{array}{c}\text { Rhodopseudomonas } \\
\text { Spheroides } \\
\text { A }\end{array}$ & $\begin{array}{l}\text { Lignite content } \\
\text { B }\end{array}$ & $\begin{array}{c}\mathrm{SRB} \\
\mathrm{C}\end{array}$ & $\begin{array}{c}\text { Particle size of } \\
\text { lignite } \\
\text { D }\end{array}$ \\
\hline $\mathrm{SO}_{4}{ }^{2-}$ Mean value 1 & 80.311 & 79.207 & 78.793 & 75.980 \\
\hline $\mathrm{SO}_{4}{ }^{2-}$ Mean value 2 & 73.050 & 77.560 & 76.027 & 77.133 \\
\hline $\mathrm{SO}_{4}{ }^{2-}$ Mean value 3 & 79.970 & 76.567 & 78.513 & 80.220 \\
\hline $\mathrm{SO}_{4}{ }^{2-}$ Range & 7.263 & 2.640 & 2.766 & 4.240 \\
\hline $\mathrm{Cu}^{2+}$ Mean value 1 & 99.430 & 97.013 & 96.787 & 96.830 \\
\hline $\mathrm{Cu}^{2+}$ Mean value 2 & 96.990 & 97.363 & 97.827 & 96.190 \\
\hline $\mathrm{Cu}^{2+}$ Mean value 3 & 94.460 & 96.503 & 96.267 & 97.860 \\
\hline $\mathrm{Cu}^{2+}$ Range & 4.970 & 0.860 & 1.560 & 1.670 \\
\hline $\mathrm{Zn}^{2+}$ Mean value 1 & 97.313 & 96.573 & 96.823 & 95.810 \\
\hline $\mathrm{Zn}^{2+}$ Mean value 2 & 96.840 & 96.120 & 96.287 & 95.610 \\
\hline $\mathrm{Zn}^{2+}$ Mean value 3 & 95.597 & 97.057 & 96.640 & 98.330 \\
\hline $\mathrm{Zn}^{2+}$ Range & 1.716 & 0.937 & 0.536 & 2.270 \\
\hline pH Mean value 1 & 7.277 & 7.290 & 7.237 & 7.240 \\
\hline pH Mean value 2 & 7.257 & 7.287 & 7.317 & 7.313 \\
\hline pH Mean value 3 & 7.380 & 7.337 & 7.360 & 7.360 \\
\hline pH Range & 0.123 & 0.05 & 0.123 & 0.120 \\
\hline COD Mean value 1 & 499.000 & 508.667 & 501.667 & 500.333 \\
\hline COD Mean value 2 & 491.667 & 494.000 & 505.333 & 494.333 \\
\hline COD Mean value 3 & 520.000 & 508.000 & 503.667 & 516.000 \\
\hline COD Range & 28.333 & 14.667 & 3.666 & 21.667 \\
\hline ORP Mean value 1 & -128.667 & -124.000 & -122.667 & -124.667 \\
\hline ORP Mean value 2 & -121.000 & -122.333 & -121.333 & -122.667 \\
\hline ORP Mean value 3 & -116.333 & -119.667 & -122.000 & -118.667 \\
\hline ORP Range & 12.334 & 4.333 & 1.334 & 6.000 \\
\hline
\end{tabular}


Table3 Variance analysis

\begin{tabular}{|c|c|c|c|c|c|c|}
\hline Source of variance & $\begin{array}{c}\text { Rhodopseudomona } \\
\text { s spheroides /A }\end{array}$ & $\begin{array}{l}\text { Lignite } \\
\text { content /B }\end{array}$ & $\mathrm{SRB} / \mathrm{C}$ & $\begin{array}{c}\text { Particle size of lignite } \\
\text { /D }\end{array}$ & Error /E & Sum \\
\hline $\mathrm{SO}_{4}{ }^{2-}$ Sum of squares of deviations & 100.760 & 10.668 & 13.916 & 28.835 & 10.670 & 164.849 \\
\hline $\mathrm{SO}_{4}^{2-}$ Free Degree & 2 & 2 & 2 & 2 & 2 & 8 \\
\hline $\mathrm{SO}_{4}{ }^{2-}$ Mean Square & 50.38 & 5.334 & 6.958 & 14.4175 & 5.335 & \\
\hline $\mathrm{SO}_{4}{ }^{2-} \mathrm{F}$ value & 9.445 & 1.000 & 1.304 & 2.703 & & \\
\hline $\mathrm{SO}_{4}^{2-} \mathrm{P}$ value & $<0.05$ & $<0.05$ & $<0.05$ & $<0.05$ & & \\
\hline $\mathrm{SO}_{4}^{2-}$ Significant & $\odot$ & $\odot$ & $\odot$ & $\odot$ & & \\
\hline $\mathrm{Cu}^{2+}$ Sum of squares of deviations & 37.055 & 1.122 & 3.786 & 4.259 & 1.12 & 47.342 \\
\hline $\mathrm{Cu}^{2+}$ Free Degree & 2 & 2 & 2 & 2 & 2 & 8 \\
\hline $\mathrm{Cu}^{2+}$ Mean Square & 18.5275 & 0.561 & 1.893 & 2.1295 & 0.56 & \\
\hline $\mathrm{Cu}^{2+} \mathrm{F}$ value & 33.026 & 1.000 & 3.374 & 3.796 & & \\
\hline $\mathrm{Cu}^{2+} \mathrm{P}$ value & $>0.05$ & $<0.05$ & $<0.05$ & $<0.05$ & & \\
\hline $\mathrm{Cu}^{2+}$ Significant & $*$ & $\odot$ & $\odot$ & $\odot$ & & \\
\hline $\mathrm{Zn}^{2+}$ Sum of squares of deviations & 4.717 & 1.316 & 0.446 & 13.789 & 0.45 & 20.718 \\
\hline $\mathrm{Zn}^{2+}$ Free Degree & 2 & 2 & 2 & 2 & 2 & 8 \\
\hline $\mathrm{Zn}^{2+}$ Mean Square & 2.3585 & 0.658 & 0.223 & 6.8945 & 0.225 & \\
\hline $\mathrm{Zn}^{2+} \mathrm{F}$ value & 10.576 & 2.951 & 1.000 & 30.917 & & \\
\hline $\mathrm{Zn}^{2+} \mathrm{P}$ value & $<0.05$ & $<0.05$ & $<0.05$ & $>0.05$ & & \\
\hline $\mathrm{Zn}^{2+}$ Significant & $\odot$ & $\odot$ & $\odot$ & $*$ & & \\
\hline $\mathrm{pH}$ Sum of squares of deviations & 0.026 & 0.005 & 0.023 & 0.022 & 0.01 & 0.086 \\
\hline pH Free Degree & 2 & 2 & 2 & 2 & 2 & 8 \\
\hline pH Mean Square & 0.013 & 0.0025 & 0.0115 & 0.011 & 0.005 & \\
\hline $\mathrm{pH} \mathrm{F}$ value & 5.200 & 1.000 & 4.600 & 4.400 & & \\
\hline $\mathrm{pH} P$ value & $<0.05$ & $<0.05$ & $<0.05$ & $<0.05$ & & \\
\hline $\mathrm{pH}$ Significant & $\odot$ & $\odot$ & $\odot$ & $\odot$ & & \\
\hline COD Sum of squares of deviations & 1297.556 & 411.556 & 20.222 & 750.889 & 20.22 & 2500.443 \\
\hline COD Free Degree & 2 & 2 & 2 & 2 & 2 & 8 \\
\hline COD Mean Square & 648.778 & 205.778 & 10.111 & 375.4445 & 10.11 & \\
\hline COD F value & 64.166 & 20.352 & 1.000 & 37.132 & & \\
\hline COD P value & $>0.05$ & $>0.05$ & $<0.05$ & $>0.05$ & & \\
\hline COD Significant & * & $*$ & $\odot$ & $*$ & & \\
\hline ORP Sum of squares of deviations & 232.667 & 28.667 & 2.667 & 56.000 & 2.67 & 322.671 \\
\hline ORP Free Degree & 2 & 2 & 2 & 2 & 2 & 8 \\
\hline ORP Mean Square & 116.3335 & 14.3335 & 1.3335 & 28 & 1.335 & \\
\hline ORP F value & 87.239 & 10.749 & 1.000 & 20.997 & & \\
\hline ORP P value & $>0.05$ & $<0.05$ & $<0.05$ & $>0.05$ & & \\
\hline ORP Significant & $*$ & $\odot$ & $\odot$ & $*$ & & \\
\hline
\end{tabular}

Note: $\mathrm{F}_{0.05}(2,2)=19, \quad \mathrm{~F}_{0.01}(2,2)=99 ; *_{0.05} \leqslant \mathrm{P} \leqslant 0.01$, significant; $\odot \mathrm{P}<0.05$ was not significant. 


\section{Reference}

1 Sun, K., Hwang, Hea, E. \& Jho. Corrigendum to "Heavy metal and sulfate removal from sulfate-rich synthetic mine drainages using sulfate reducing bacteria" [Sci. Total Environ. 635 (2018) 1308-1316]. The Science of the total environment, doi:10.1016/j.scitotenv.2018.10.142 (2018).

Watanabe, M., Higashioka, Y., Kojima, H. \& Fukui, M. Proposal of Desulfosarcina ovata subsp. sediminis subsp. nov., a novel toluene-degrading sulfate-reducing bacterium isolated from tidal flat sediment of Tokyo Bay. Systematic and Applied Microbiology 43, 126109, doi:10.1016/j.syapm.2020.126109 (2020).

Tran, T. T. T., Kannoorpatti, K., Padovan, A. \& Thennadil, S. Sulphate-Reducing Bacteria's Response to Extreme pH Environments and the Effect of Their Activities on Microbial Corrosion. Applied Sciences 11, 2201, doi:10.3390/app11052201 (2021).

Zhang, Q. Preparation of Coal-based Adsorbent and the removal of Heavy Metals from Waste Water, Wuhan University of Science and Technology.

An, W., Wang, L. \& Di, J. Dynamic Experimental Study on the Iron Cooperated with SRB Sludge Immobilized Particles to Treat AMD. Non-Metallic Mines (2017).

Junzhen, D. I. et al. Best conditions of modification about corncob as SRB fixed carbon source. Chinese Journal of Environmental Engineering (2017).

Zhu, Z. Study on Acid Waste water of SRB sludge particles, Fuxin: Liaoning University of Engineering and Technology, (2015).

Chen, Y. The extraction solvent of tangerine total flavonoids was screened by orthogonal analysis. Everybody Health (Academic) 6, 4-6, doi:CNKI:SUN:JKXS.0.2012-12-003 (2012).

Kiran, M. G., Pakshirajan, K. \& Das, G. Metallic wastewater treatment by sulfate reduction using anaerobic rotating biological contactor reactor under high metal loading conditions. Academic abstracts of Chinese colleges and universities · environmental science and Engineering 012, 111-121, doi:10.1007/s11783-018-1073-4 (2018).

0 Zhu, Y. Language-based orthogonal experimental extreme analysis - takes the orthogonal table of L-9(3 4) without interaction as an example. Beverage Industry, 31-34, doi:CNKI:SUN:RYLG.0.2011-02-021 (2011).

Lin, Y. et al. Preparation and characterization of magnetic Fe3O4-chitosan nanoparticles for cellulase immobilization. Cellulose, doi:10.1007/s10570-017-1520-6 (2017).

Dongmei, Z., Shiwei, Z., Huanchi, M. \& Huiying, L. Simulation of Methylmercury Content and SRB Methylation in Phragmites australis Soil Under Different Salinity Conditions. Water, Air, and Soil Pollution 231, 18.11-18.18, doi:10.1007/s11270-019-4382-8 (2020).

Yu, H. et al. Transcriptome Analysis of the Acid Stress Response of Desulfovibrio vulgaris ATCC 7757. Current Microbiology, doi:10.1007/s00284-020-02051-x (2020).

Pantoja-Guerra, M. \& Valero-Valero, N. Design of a bio-conditioner prototype for the treatment of degraded soils: biomass production and lignite formulation for Microbacterium sp. CSB3. Chemical and Biological Technologies in Agriculture 7, 3, doi:10.1186/s40538-019-0167-y (2020).

Nelson, V., Liliana, G., Manuel, P. \& Ramiro, R. Production of humic substances through coal-solubilizing bacteria. Brazilian Journal of Microbiology 45, doi:10.1590/S1517-83822014000300021 (2014).

Dong, Y. et al. Dynamic Experimental Study on Treatment of Acid Mine Drainage by Bacteria Supported in Natural Minerals. Energies 13, doi:10.3390/en13020439 (2020).

B, D. M. A. \& A, S. C. Single, binary, and multicomponent sorption of iron and manganese on lignite - ScienceDirect. Journal of Colloid and Interface Science 299, 76-87, doi:10.1016/j.jcis.2006.02.010 (2006).

B, D. M. A. \& A, S. C. Single, binary, and multicomponent sorption of iron and manganese on lignite - ScienceDirect. Journal of Colloid and Interface Science 299, 76-87, doi:10.1016/j.jcis.2006.02.010 (2006). 
Hao, Y., Fan, F. \& Guo, C. Thermodynamic mechanism of copper adsorption in lignite. Material Protection 07, 85-88, doi:CNKI:SUN:CLBH.0.2017-07-023 (2017).

20 Detmers, J., Schulte, U., Strauss, H. \& Kuever, J. Sulfate Reduction at a Lignite Seam: Microbial Abundance and Activity. Microb Ecol 42, 238-247, doi:10.1007/s00248-001-1014-8 (2001).

21 Xue, L. Experimental study on the repair of acid wastewater, Liaoning University of Engineering and Technology, (2019).

22 Xin, F., Xu, H., Tang, D. \& Cao, L. Properties of lignite and key factors determining the methane adsorption capacity of lignite: New insights into the effects of interlayer spacing on adsorption capacity. Fuel Processing Technology 196, 106181, doi:10.1016/j.fuproc.2019.106181 (2019).

23 Chethan, P. D. \& Vishalakshi, B. Adsorption Efficiency of Cr(VI) by Ethylene-1,2- Diamine-6-Deoxychitosan. Separation Science and Technology 50, 1158-1165, doi:10.1080/01496395.2014.967405 (2015).

24 Panadare, D. C., Lade, V. G. \& Rathod, V. K. Adsorptive removal of copper(II) from aqueous solution onto the waste sweet lime peels (SLP): equilibrium, kinetics and thermodynamics studies. Desalination \& Water Treatment 52, 7822-7837, doi:10.1080/19443994.2013.831789 (2014).

25 Mhca, B. et al. Preparation, characterization and adsorption kinetics of methylene blue dye in reduced-graphene oxide supported nanoadsorbents - ScienceDirect. Journal of Molecular Liquids 309, doi:10.1016/j.molliq.2020.113171.

26 Agarry, S. E., Ogunleye, O. O. \& Aworanti, O. A. Biosorption equilibrium, kinetic and thermodynamic modelling of naphthalene removal from aqueous solution onto modified spent tea leaves. Environmental Technology 34, 825-839, doi:10.1080/09593330.2012.720616 (2013).

27 Bao, X. Absorption and mechanism of modified lignite, Henan: Henan Agricultural University.

28 Vimonses, V., Lei, S., Jin, B., Chow, C. \& Saint, C. Kinetic study and equilibrium isotherm analysis of Congo Red adsorption by clay materials. Chem.eng.j 148, 354-364, doi:10.1016/j.cej.2008.09.009 (2010).

Acknowledgements: This paper was funded by the National Natural Science Foundation of China (41672247); Support for the "Rejuvenating Liaoning Talents" youth top talent program of Liaoning Province (XLYC1807159); Project supported by discipline innovation team of Liaoning University of engineering and Technology (Project Number: LNTU20TD-21).

Author contributions statement: All authors contributed to the study conception and design. Material preparation, data collection and analysis were performed by Di Junzhen, Jiang Yangyang and Wang Mingjia. The first draft of the manuscript was written by Jiang Yangyang and Dong Yanrong, and all authors commented on previous versions of the manuscript.

Additional information: The authors declare that there is no conflict of interest regarding the publication of this article.

1 School of Civil Engineering, Liaoning University of Engineering and Technology, Fuxin, Liaoning Province 123000, China

* corresponding author: dijunzhen@126.com 
Figures

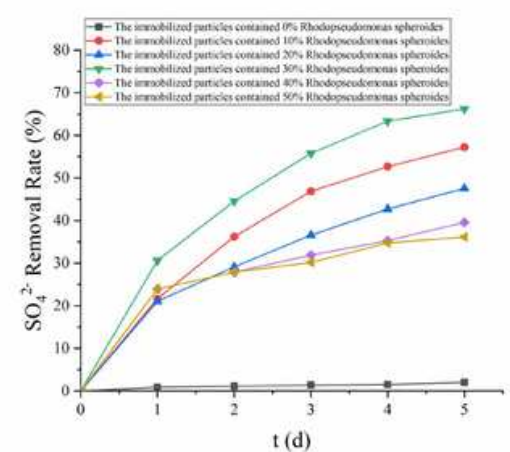

(a) $\mathrm{SO}_{4}{ }^{2-}$ removal rate

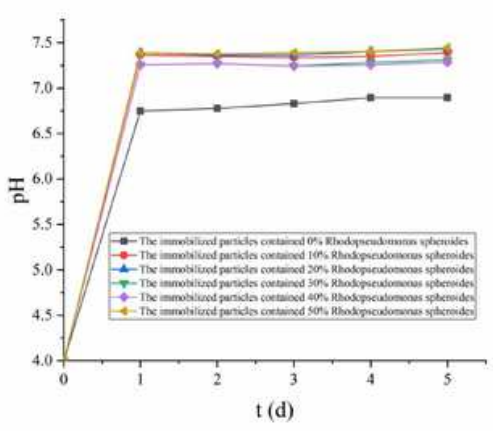

(d) $\mathrm{pH}$ change

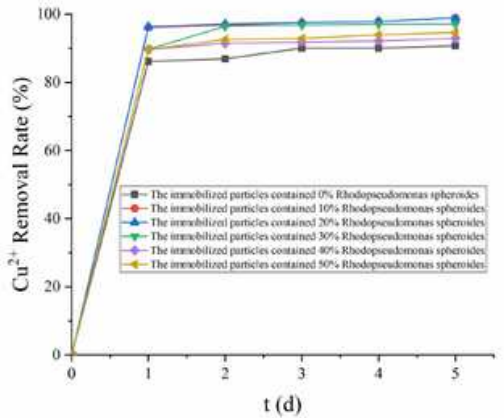

(b) $\mathrm{Cu}^{2+}$ removal rate

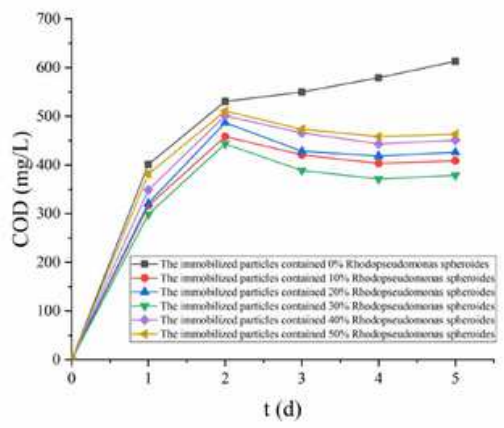

(e) COD change

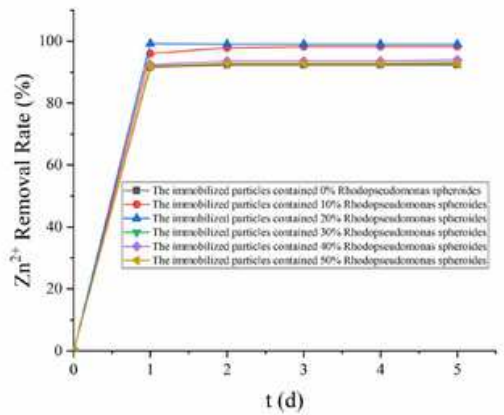

(c) $\mathrm{Zn}^{2+}$ removal rate

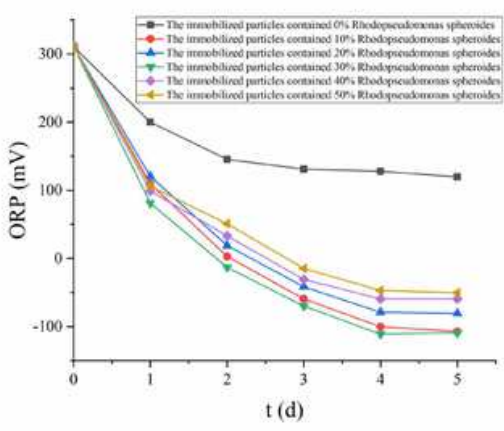

(f) ORP change

\section{Figure 1}

Effects of different dosages of Rhodopseudomonas Spheroides on various indexes 


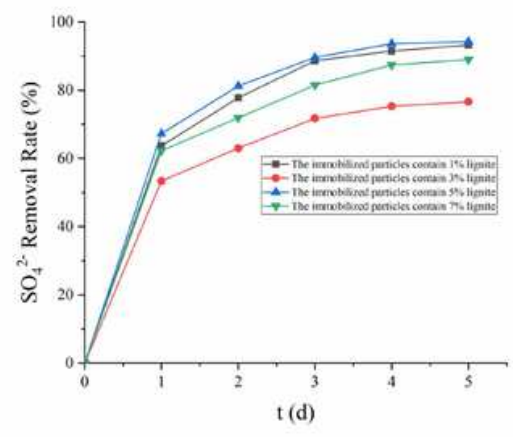

(a) $\mathrm{SO}_{4}{ }^{2-}$ removal rate

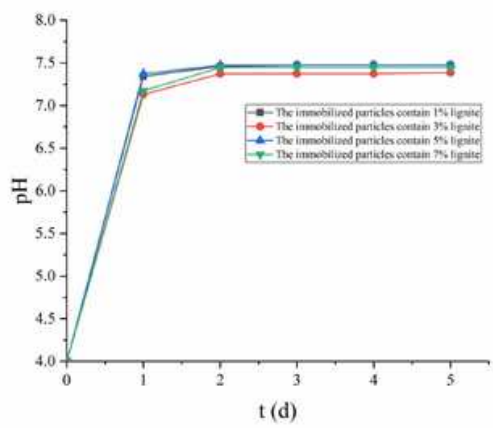

(d) $\mathrm{pH}$ change

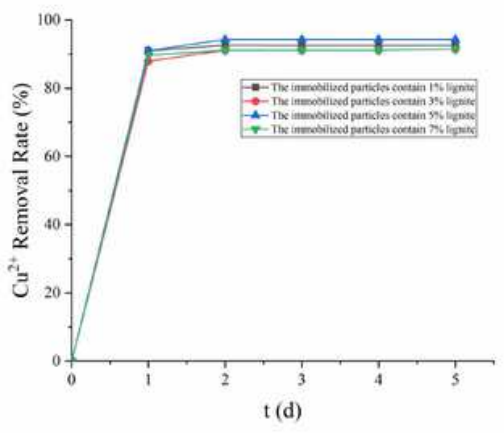

(b) $\mathrm{Cu}^{2+}$ removal rate

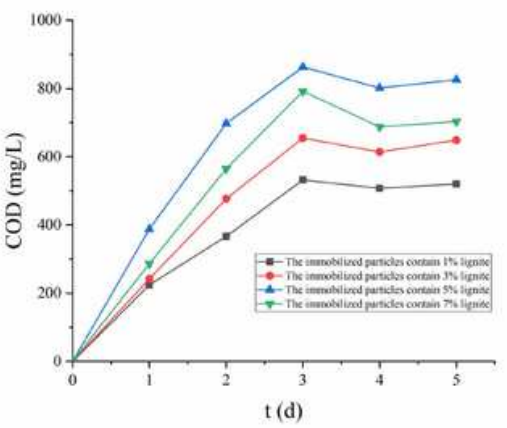

(e) COD change

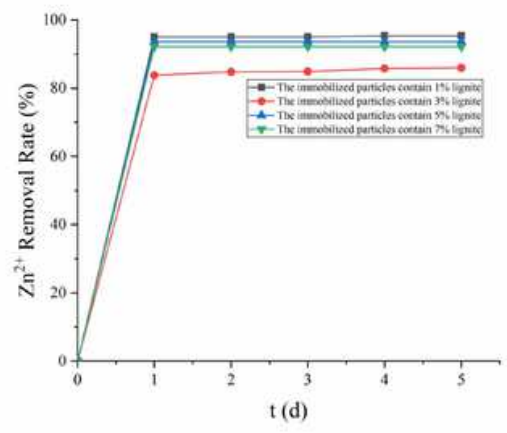

(c) $\mathrm{Zn}^{2+}$ removal rate

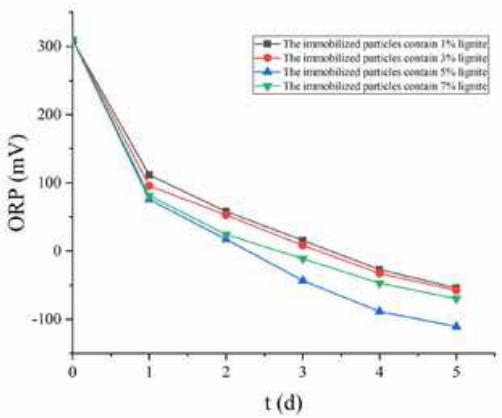

(f) ORP change

\section{Figure 2}

\section{Effect of different dosage of lignite on various indexes}

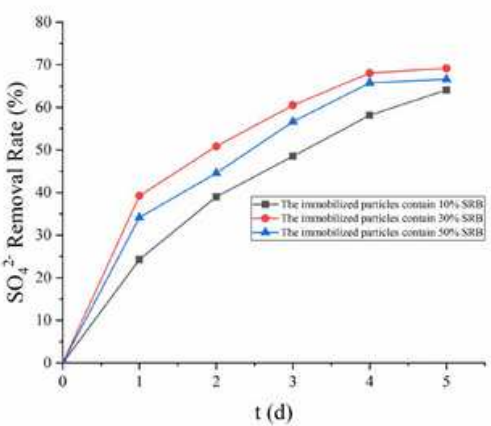

(a) $\mathrm{SO}_{4}{ }^{2-}$ removal rate

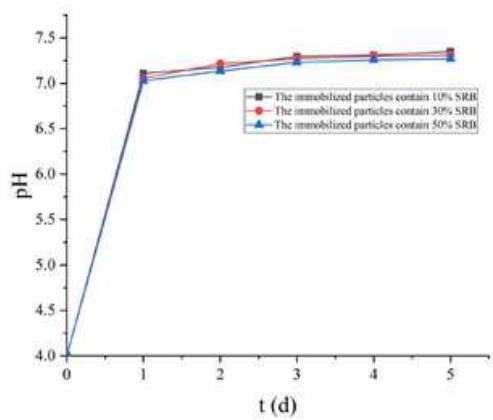

(d) $\mathrm{pH}$ change

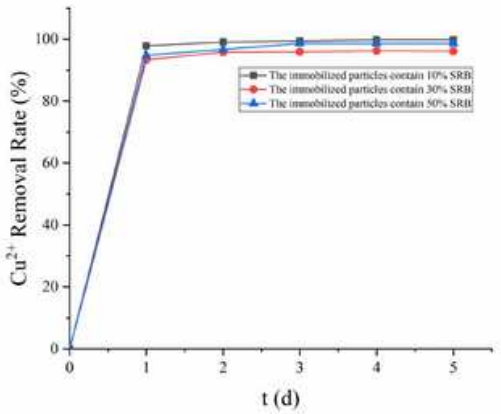

(b) $\mathrm{Cu}^{2+}$ removal rate

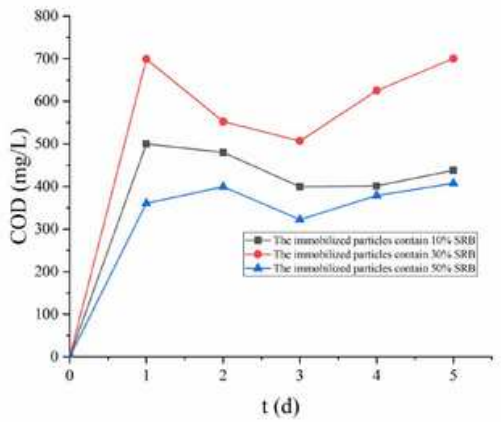

(e) COD change

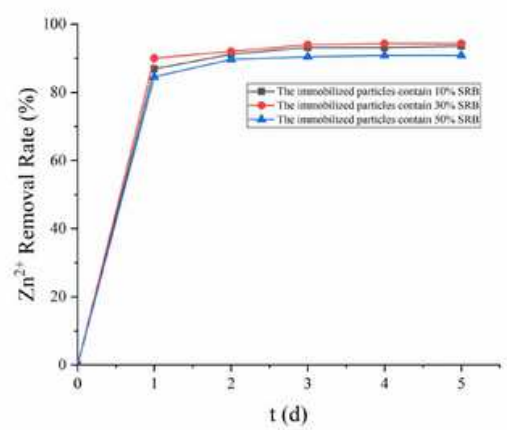

(c) $\mathrm{Zn}^{2+}$ removal rate

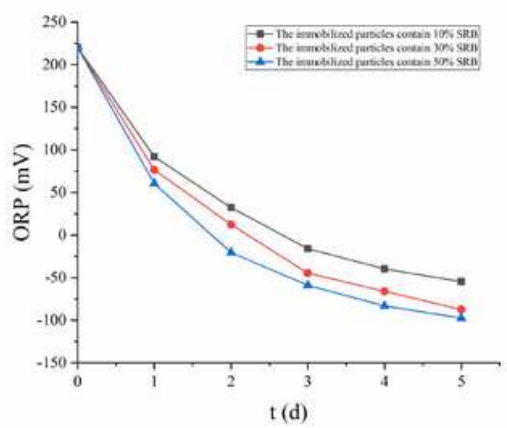

(f) ORP change 
Figure 3

Effects of SRB dosage on various indexes

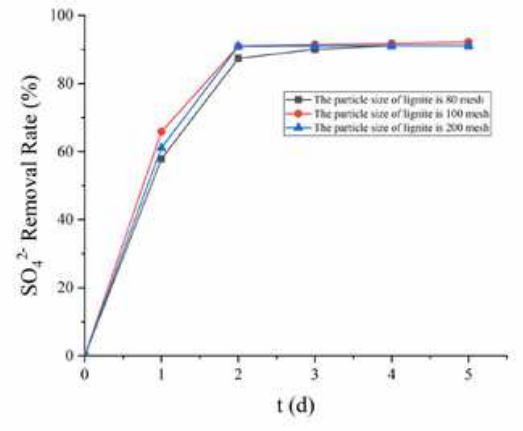

(a) $\mathrm{SO}_{4}{ }^{2-}$ removal rate

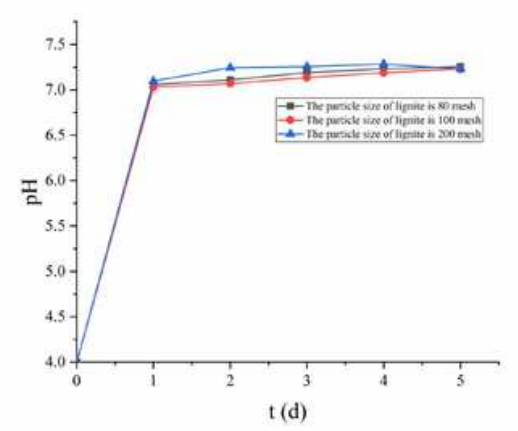

(d) $\mathrm{pH}$ change

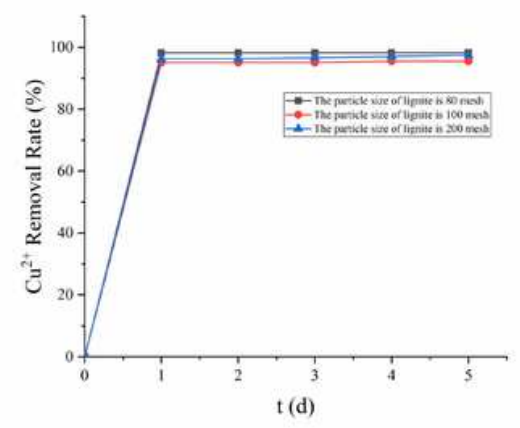

(b) $\mathrm{Cu}^{2+}$ removal rate

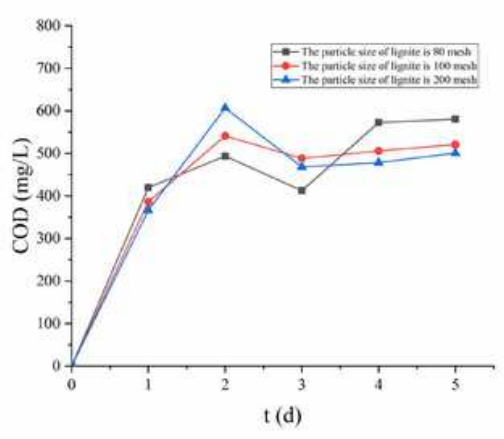

(e) COD change

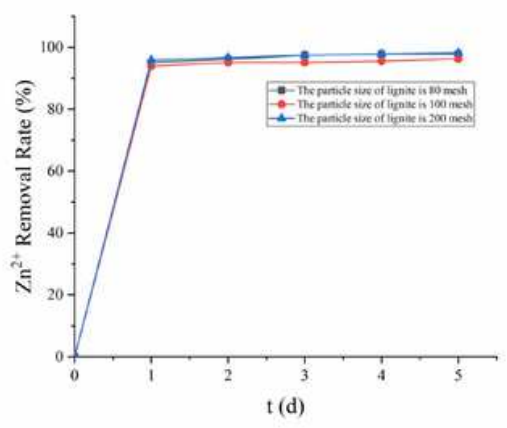

(c) $\mathrm{Zn}^{2+}$ removal rate

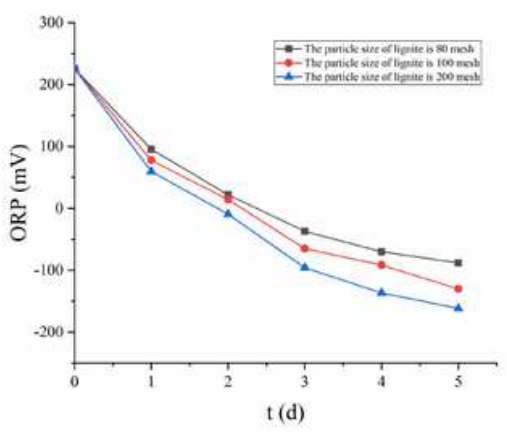

(f) ORP change

Figure 4

Effect of different particle size of lignite on various indexes 


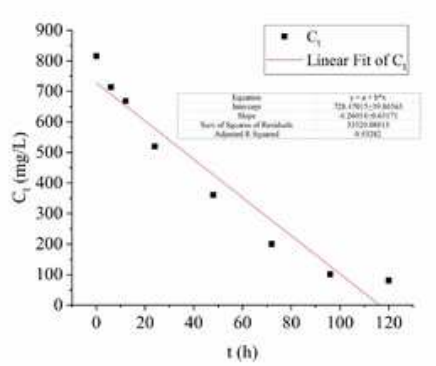

(a) The concentration of $\mathrm{SO}_{4}{ }^{2-}$ at $t$

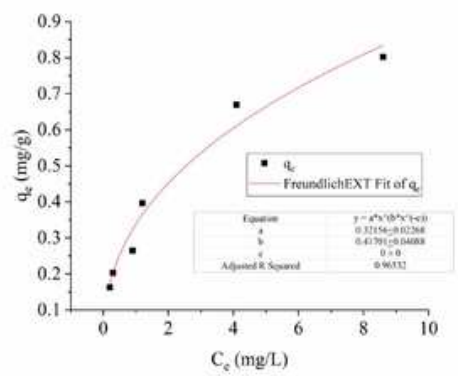

(d) Adsorption isotherm fitting Freundlich models of $\mathrm{Zn}^{2+}$

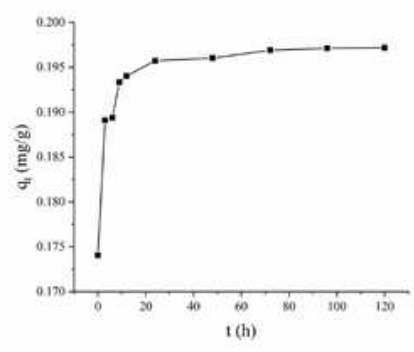

(g) $\mathrm{Zn}^{2+}$ adsorption curve 2

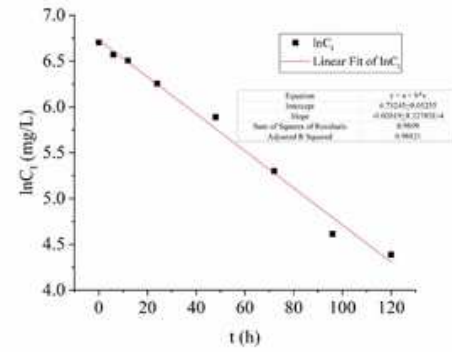

(b) Logarithm of $C_{\text {, }}$

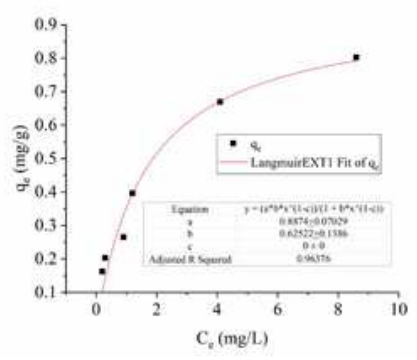

(e)Adsorption isotherm fitting Langmuir models

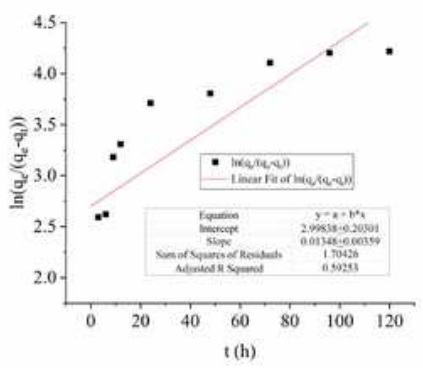

(h) Quasi first model

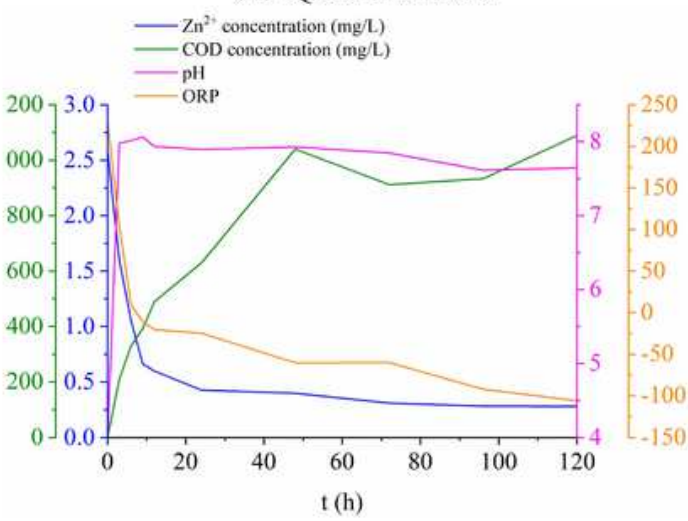

(j) Changes of four indexes of $\mathrm{Zn}^{2+}$ solution

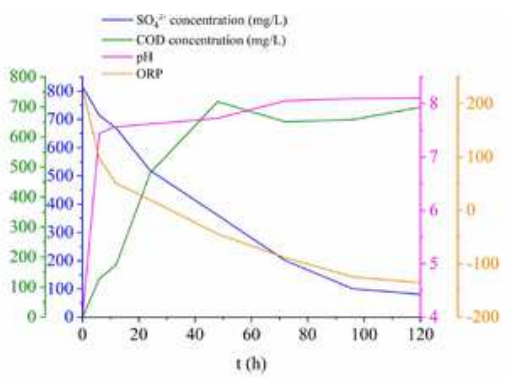

(c) Changes of four indexes of $\mathrm{SO}_{4}{ }^{2-}$ solution

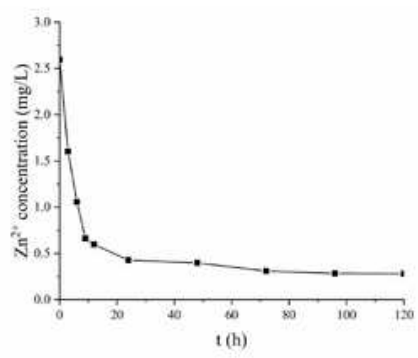

(f) $\mathrm{Zn}^{2+}$ adsorption curve 1

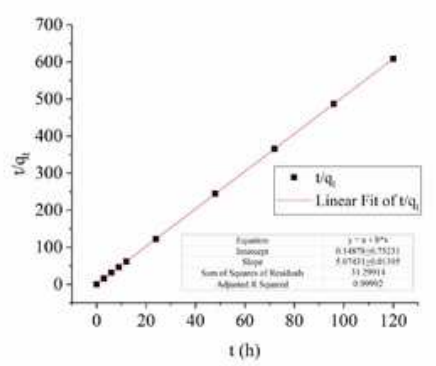

(i) second kinetic model

\section{Figure 5}

Fitting curves

\section{Supplementary Files}

This is a list of supplementary files associated with this preprint. Click to download. 
- SupplementaryFigureS1.pdf

- SupplementaryFigureS2.pdf 